\title{
Parents' Views in Preparing Children with Special Needs Towards Inclusive Education
}

\author{
Amka* Dewi Ratih Rapisa \\ Special Education, Lambung Mangkurat University, Banjarmasin 70123, \\ South Kalimantasn, Indonesia
}

\begin{abstract}
Inclusive education teaches many people to be able to appreciate and accept differences, and it is hoped that the benefits of inclusive education can be felt by all sections of society (regular children, parents of regular children, teachers, and the general public) in learning and getting to know about different people with themself. Facts on the area show that there are still some obstacles in the implementation of inclusive education so that the goals and benefits of inclusive education are still not optimally felt by children or parents of children with special needs. This study purposes to determine the views of parents towards inclusive education, so that through the responses provided can be the basis for preparing better inclusive education. The method used in this research is qualitative with the type of case studies and uses interview techniques and questionnaires to collect data. The results of the study are the discovery of data regarding parents' knowledge, understanding, and trust in schools and government in relation to the implementation of inclusive education.
\end{abstract}

Keywords: parents' views, children with special needs, inclusive education

DOI: $10.7176 / \mathrm{JEP} / 11-2-10$

Publication date: January $31^{\text {st }} 2020$

\section{Introduction}

Children with special needs are children who have physical, emotional, mental, social, or a combination of these characteristics that are not the same as children in general and cause obstacles in achieving optimal developmental tasks that require special education services (Iswori, in Mustolih , 2018, p. 86). One form of special education services purposeed at children with special needs is inclusive education. The implementation of inclusive education purposes to accommodate children with special needs in obtaining education that is integrated with regular schools that are carried out sustainably (Darmono, 2015, p.5). Inclusive education is concerned with overcoming obstacles that prevent the participation and learning of all children, regardless of race, gender, social background, gender, disability, and achievement of learning outcomes in schools (Booth T and Ainscow, 1998).

The success of inclusive schools can be achieved if it involves many parties (Sunaryo, 2009), namely the government, schools, the community, and parents of children with special needs. Inclusive education requires joint efforts by teachers, families, students and principals to design inclusive policies, build positive cultures and implement practices that increase the level of effective teaching and learning (Ainscow 1999). The actual criteria for successfully implementing a more inclusive system ultimately depends on what happens in schools and classrooms (Ainscow, 2007). Successful implementation of inclusive education depends on the existence of a support system, which includes teacher training, resources for schools, social support, and community participation, for example developing collaborative relationships among staff and with parents, as well as collaborative relationships with organizations involved in the community (Kantavong, 2018).

Given the success of the delivery of inclusive education for children with special needs is not limited to the achievement of academic service delivery, but also important to develop social relations throughout the school community. The social dimension is seen as an important aspect in implementing inclusive education successfully (Anke de Boer, Sip Jan Pijl and Alexander Minnaert) in Koster, Pijl, Nakken and Houten, 2010.

Most parents of children with special needs assume that they will benefit positively in academic terms if they send their children to regular schools providing inclusive education (Frederickson, Dunsmuir, Lang, \& Monsen, 2004). On the other hand, the main motives of parents of children with special needs prefer to send their children to regular schools providing inclusive education rather than in special schools or in special schools because parents assume that the social opportunities of children with special needs will increase in inclusive schools (Scheepstra, 1998, quoted in Nakken \& Pijl, 2002; Sloper \& Tyler, 1992).

The involvement of parents of children with special needs is so that each child gets the same learning opportunities and can develop according to their potential. There are five roles of parents in handling and serving children with special needs, namely as the main companion (helping to achieve the goals of handling and education services of children), as an advocate (who understands, strives, and maintains children's rights in the opportunity to receive educational services according to their needs), as a source (being a source of complete and correct data about a child's self in an effort to intervene in a child's behavior), as a teacher (acting as an educator for children in daily life outside school hours), and as a diagnostic (determining the characteristics and types of special needs and able to do treatment, especially outside school hours) (Hewett and Frenk, In Darmono, 2015, p. 14). 
Based on this role, it can be seen that the involvement of parents greatly influences the education of children with special needs and is a driving factor and determinant of the development of inclusive education. This is evidenced by the many policies that include parents in making decisions about education for their children who have special needs. Understanding and documentary evidence that is owned by parents relating to the condition of the child becomes a source for the school and other professional experts in facilitating and making programs that fit the child's needs (Amin, 2018). Another role that parents have is as a collaborator because through information obtained from professional experts, parents are required to be able to implement services related to children's needs at home. The roles above show that parents have a big influence in the implementation of inclusive education, this is because the subject in inclusive education is children and services that meet their needs, and parents play a role in supporting the implementation and achievement of the rights of education owned by children.

In its implementation, inclusive education still has obstacles in fulfilling the educational rights of children with special needs. Problems that arise can be sourced from teachers, students, parents, schools, communities, government, and the lack of infrastructure that supports the implementation of inclusive schools (Jauhari, 2017, p. 60). This research focuses on the perspective of parents as one of the parties who have a major influence on the success of inclusive education. The study was conducted to determine the views of parents on inclusive education that have been carried out, then become the basis in preparing children to be able to participate in inclusive education better. The purpose of this study is to find out the knowledge and understanding of parents about inclusive education, and to find out the beliefs of parents about the attitudes of key stakeholders (schools and government) towards inclusive education.

\section{Method}

This research was conducted using a qualitative approach, namely research with the purpose to understand phenomena regarding things experienced by research subjects such as actions, motivations, perceptions, etc. holistically through descriptions or words (Moelong, 2008, in Irkhamiyati, 2017, p. 41). The design used is a case study, which is in-depth and specific research on a case related to the fields of health, law, business, and social science (Fraenkel, Wallen, \& Hyun, 2012).

The type of sample used in the study is a purposive sample, namely the selection of sources or sources of data based on the purpose of the study and is considered to have the information needed (Surayya, 2018, p. 80). The source of the research data is the parents of children with special needs totaling 14 (fourteen) people, with different conditions for children as students from inclusive schools in Banjarmasin. The research location is located at Happy Kids Growth and Development Clinic, located at Jl. K. S. Tubun No. 165 Banjarmasin. Data collection was carried out using questionnaires and interviews about the views of parents in preparing children with special needs towards inclusive education. There is also a research analysis conducted descriptively to explain the research findings that have been obtained. All respondents' statements through questionnaires are grouped into the Liket 5 scale options ranging from strongly agree, agree, doubt or doubt, disagree, and strongly disagree. In addition, respondents' statements through interviews were used to complement the findings in the field, especially those related to school management and the condition of teachers found by parents when involved in inclusive schools.

\section{RESULTS AND DISCUSSION}

Based on a questionnaire distributed to 14 (fourteen) parents with Children with Special Needs, the following are the results obtained regarding the views of parents in preparing children with special needs towards inclusive education, that is:

Table 1. Research Questionnaire Results

\begin{tabular}{|c|l|c|c|c|c|c|}
\hline \multirow{2}{*}{ Item Statement } & \multicolumn{1}{|c|}{$\begin{array}{c}\text { Strongly } \\
\text { Agree }\end{array}$} & Agree & Undecided & Disagree & $\begin{array}{c}\text { Strongly } \\
\text { Disagree }\end{array}$ \\
\cline { 3 - 7 } 1 & $\begin{array}{l}\text { Inclusive education respects and } \\
\text { embraces children's differences }\end{array}$ & $71,4 \%$ & $28,6 \%$ & - & - & $(3)$ \\
\hline 2 & $\begin{array}{l}\text { Inclusive education accepts all } \\
\text { conditions of children }\end{array}$ & $64,3 \%$ & $35,7 \%$ & - & - & - \\
\hline 3 & $\begin{array}{l}\text { Inclusive education guarantees children } \\
\text { have access to education in the area } \\
\text { where they live }\end{array}$ & $42,9 \%$ & $57,1 \%$ & - & - & - \\
\hline 4 & $\begin{array}{l}\text { Inclusive education creates a conducive } \\
\text { learning environment for all children }\end{array}$ & $64,3 \%$ & $35,7 \%$ & - & - & - \\
\hline 5 & $\begin{array}{l}\text { Inclusive education encourages } \\
\text { children's participation in learning }\end{array}$ & $64,3 \%$ & $35,7 \%$ & - & - & - \\
\hline 6 & $\begin{array}{l}\text { Inclusive education accommodates the } \\
\text { special needs of children }\end{array}$ & $71,4 \%$ & $28,6 \%$ & - & - & - \\
\hline
\end{tabular}




\begin{tabular}{|c|l|c|c|c|c|c|}
\hline \multirow{2}{*}{ Item Statement } & $\begin{array}{c}\text { Strongly } \\
\text { Agree }\end{array}$ & Agree & Undecided & Disagree & $\begin{array}{c}\text { Strongly } \\
\text { Disagree }\end{array}$ \\
\cline { 3 - 6 } & \multicolumn{1}{|c|}{$(1)$} & $(2)$ & $(3)$ & $(4)$ & $(5)$ \\
\hline 7 & $\begin{array}{l}\text { Inclusive education develops children's } \\
\text { potential }\end{array}$ & $64,3 \%$ & $35,7 \%$ & - & - & - \\
\hline 8 & $\begin{array}{l}\text { I believe the government supports } \\
\text { inclusive education }\end{array}$ & $50 \%$ & $42,9 \%$ & $7,1 \%$ & - & - \\
\hline 9 & $\begin{array}{l}\text { I believe that school principals and } \\
\text { teachers can implement inclusive } \\
\text { education in schools }\end{array}$ & $28,6 \%$ & $50 \%$ & $21,4 \%$ & - & - \\
\hline 10 & $\begin{array}{l}\text { I believe parents and regular children can } \\
\text { receive the implementation of inclusive } \\
\text { education in schools }\end{array}$ & $28,6 \%$ & $50 \%$ & $21,4 \%$ & - & - \\
\hline
\end{tabular}

Based on the table above, it can be seen that as follows:

1. In the first question, there were $71.4 \%$ of the 10 (ten) parents who strongly agreed and $28.6 \%$ of the 4 (four) parents who agreed that inclusive education respected and embraced the differences of children.

2. In the second statement, there were $64.3 \%$ of 9 (nine) parents who stated strongly agree and $35.7 \%$ of 5 (five) parents who agreed that inclusive education accepted all conditions of the child.

3. In the third statement, there were $42.9 \%$ of 6 (six) parents who stated strongly agree and $57.1 \%$ of 8 (eight) parents who agreed that inclusive education guarantees children have access to education in the area of their residence.

4. In the fourth statement, there were $64.3 \%$ of 9 (nine) parents who stated strongly agree and $35.7 \%$ of 5 (five) parents who agreed that inclusive education creates a conducive learning environment for all children.

5. In the fifth statement, there were $64.3 \%$ of 9 (nine) parents who stated strongly agree and $35.7 \%$ of 5 (five) parents who agreed that inclusive education encourages children's participation in learning.

6. In the sixth statement, there were $71.4 \%$ of 10 (ten) parents who strongly agreed and $28.6 \%$ of 4 (four) parents who agreed that inclusive education accommodated the special needs of children.

7. In the seventh statement, there were $64.3 \%$ of 9 (nine) parents who agreed strongly and $35.7 \%$ of 5 (five) parents who agreed that inclusive education developed children's potential.

8. In the eighth statement, there were $50 \%$ of 7 (seven) parents who stated strongly agree and $42.9 \%$ of 6 (six) parents who agreed and $7.1 \%$ of 1 (one) parent who expressed doubt that they believe the government supports inclusive education.

9. In the ninth statement, there were $28.6 \%$ of the 4 (four) parents who strongly agreed and $50 \%$ of the 7 (seven) parents who agreed and $21.4 \%$ of the 3 (three) parents who expressed doubt that they believe the principal and teachers can implement inclusive education in schools.

10. In the tenth statement, there were $28.6 \%$ of the 4 (four) parents who stated strongly agree and $50 \%$ of 7 (seven) parents who agreed and $21.4 \%$ of the 3 (three) parents who expressed doubt that they believe parents and regular children can receive the implementation of inclusive education in schools.

In addition to the results of the questionnaire, this study also found interview notes to parents regarding the views of parents in preparing children with special needs towards inclusive education. The results of the interview are summarized as follows:

1. Inclusive education respects and embraces children's differences

"Inclusive education can reduce fear of friendship, responsibility and self-understanding." (AKL, 6 July 2019)

2. Inclusive education accepts all conditions of the child

"In the learning process, it is not the child who adjusts the curriculum, but the curriculum that has to adjust to the needs of the child." (ARP, 6 July 2019)

3. Inclusive education guarantees children have access to education in the area of residence

"As parents are grateful that inclusive education can provide guarantees that children have access to education in the area where they live." (RE, 6 July 2019)

4. Inclusive education creates a conducive learning environment for all children

"Hopefully, regular children can respect children with different conditions and want to get along with children with special needs, accept and recognize children with special needs as fellow class members." (ANS, 6 July 2019)

5. Inclusive education encourages children's participation in learning

"I hope that with inclusive education, all children can have the right to learn together with other children without exception." (HMS, 6 July 2019)

6. Inclusive education accommodates the special needs of children

"The learning process in the classroom has not run optimally due to the lack of special education experts in schools so that children are only accepted while the needs of children are not served." (YDEW, 6 July 2019) 
7. Inclusive education develops children's potential "By attending inclusive education, I hope my child who has limited abilities can develop more optimally because he is involved in normal activities with other regular children." (KMD, 6 July 2019)

8. Parents believe the government supports inclusive education "The provincial government has not provided Special Education Teachers (GPK), even if there is in general still a school initiative funded by parents' self-funding. Until now, the Regional Government has not provided formation for Civil Servants (PNS) for GPK in inclusive schools. The training for non-special education teachers is not yet optimal to improve teacher competence in order to serve children with special needs. "(IMD, 6 July 2019)

9. Parents believe that school principals and teachers can implement inclusive education in schools "... the lack of teacher understanding of children with special needs and inappropriate educational background of teachers." (WF, 6 July 2019)

10. Parents believe that parents and regular children can receive the implementation of inclusive education in schools

"As parents, of course they have high hopes for inclusive education so that their children can be well served. Hopefully there is no educational discrimination for children who have obstacles. "(LS, 6 July 2019)

The results of the questionnaire that have been distributed show that not all parents of children with special needs express strongly agree and agree to statements about inclusive education. Moreover, there are even parents of children with special needs who expressed doubts about statements about inclusive education. This shows that the views of parents are quite varied ranging from guidance, agree and strongly agree in preparing children with needs towards inclusive education. On the other hand, parents of children with special needs have high hopes for the implementation of inclusive education so that the rights of education in children with special needs can be achieved and children can develop optimally based on their potential and needsThe results of the first and sixth point questionnaire are statements that inclusive education respects and embraces the differences of children, and is able to accommodate the needs of children responded strongly agreed by ten parents, while the statement of agreement only responded by four parents. Based on the responses given by the parents of children with special needs in the inclusive schools interviewed, it shows that the implementation of inclusive education in Banjarmasin has been implemented well, although in reality there are still some deficiencies that become obstacles in implementation. In South Kalimantan still faces a number of obstacles in implementing inclusive education. The constraints referred to include the Provincial Government not providing Special Education Teachers (GPK), even if there is in general still a school initiative funded by school funds and assistance from parents of children with special needs. Limited funding caused GPK to receive a small honorarium that was not up to standard. Another obstacle is the very small number of GPK graduates so that many general teachers are empowered by providing special education training. Training is given to non-graduate teachers of special education so that competency is not optimal. The Local Government does not provide formation for GPK civil servants (PNS) in inclusive schools. The Regional Government has indeed formed an Inclusive Education Communication Forum (FKPI) but its role is limited to promoting inclusive policies, and has not been able to be a place to help solve technical problems of inclusive learning practices (Amka, 2019). Tarnoto (2016) also found a number of things that were obstacles to the implementation of inclusive education were teachers and school management, problems in teachers serving children with special needs were the lack of teacher understanding of $\mathrm{ABK}$, and the inappropriate educational background of teachers. There are also problems in school management in the form of not being ready for schools with inclusive school programs both in terms of administration and human resources, as well as the process of teaching and learning that has not run optimally or the lack of special education experts in schools so that children are only accepted, while the needs of children are not served.

In essence the function of inclusive education is to ensure that all children with special needs get equal opportunities and access to education services that are suitable to their needs and quality in various channels, types, and levels of education and create an educational environment conducive to developing children's potential optimally (Custarians) , 2013). The things that are obtained by children in accessing their educational rights will also be felt and affect the perspective and attitude of parents towards inclusive education. Based on the number of very satisfied responses given by parents shows that parents have felt the function and benefits of inclusive education.

Inclusive education accepts all conditions of the child, can create a conducive learning environment, encourages children's participation in learning, and develops the child's potential is a statement that is responded to with the agreement of nine parents on each item, while five other parents agree to the statement. In the ninth item, which is a statement about the parents' belief in the principal and the teacher can implement inclusive education in schools, the response was strongly agreed by four parents, seven parents who agreed, and 3 parents responded uncertainly.

The existence of inclusive education is not only important to accommodate children with special needs in an integrated school, but is also intended to develop their potential and save their future from educational 
discrimination which tends to ignore children who have barriers (Divine, 2013). The difference in response shows that each parent has a different experience so that it affects the views of parents about inclusive education services. On the one hand it is also seen that parents have high hopes for inclusive education so that their children can be well served.

Based on the responses given, it can be said that the benefits of inclusive education have been felt by parents, because in inclusive education, the fulfillment of the needs of children with disabilities does not start from the child's adjustments to the education system, methods, or the environment, but vice versa. In the classroom atmosphere, it is not the child who adjusts the curriculum, but the curriculum that must be adapted to the needs of the child (Jauhari, 2017).

There is a sense of trust in the government in supporting inclusive education and guarantees that children have access to education in the area where they live receives a very much less agreed response when compared to previous statements. Inclusive problems that arise related to the government are the lack of attention or concern for the government towards the implementation of inclusive schools, especially those located in the district areas, the lack of training on inclusive education for teachers living in the regions, and there is no specific institution that handles ABK mentoring training (Jauhari, 2017 , p. 55), because until now parents sometimes find it difficult to find a companion who has good understanding and skills in dealing with children with special needs. The lack of service centers for children with special needs in districts such as special schools, inclusive schools, and growth and development clinics also become a separate obstacle for parents in accessing education in accordance with the needs of children.

In the 1945 Constitution article 31 paragraph 1 and Law No. 20 of 2003 concerning the National Education System it can be concluded that the state provides full guarantees to children with special needs to obtain quality educational services. The aim of inclusive education is to minimize the limitations of the child's growth and development conditions and to maximize the opportunities of the child to engage in normal activities and if possible to prevent the occurrence of more severe conditions in irregular development so as to become a child with no ability and to prevent the development of other limited abilities as the results caused by the main inability (Saputra, 2016, p. 12). Based on the basis and objectives of inclusive education, the government should try to optimize all means in order to achieve the goals of inclusive education. Inclusive education is very important to develop because all children have the right to learn together, there is no fundamental reason to separate children, research shows that children tend to show good results academically and socially when they are in a shared setting, there is no educational service in SLB who are able to take part in dealing with children in school in general, all children need education that can develop relationships between individuals and prepare to live in their communities, and only inclusive education has the potential to suppress fear in building friendship, responsibility, and understanding self (Purwanta, 2002). The existence of a legal basis makes parents have great hopes that education can be carried out well so that each child can grow and develop based on their potential.

The last statement, which is the belief that parents and regular children can accept the implementation of inclusive education in schools, was responded to strongly in agreement by four parents, seven parents responded in agreement, and three parents responded uncertainly. The fear of parents usually arises because people around the environment, or new environments such as when children will go to school with an inclusive setting feel worried if children with special needs will be viewed and treated differently. Inclusive education teaches many people to be able to appreciate and accept differences, and it is hoped that the benefits contained in inclusive education, namely regular children can learn and get to know people who are different from themselves. Regular children can respect people with different conditions, both from the way they learn, physically and emotionally through various experiences gained from inclusive schools, changing negative views from educators or other students about children with special needs, and those who start to interact with children. those with special needs begin to accept and recognize them as valuable class members (Wijiastuti, 2018).

Inclusive education is a model that introduces and teaches the community (regular children, parents of regular children, and society in general) to recognize differences, diversity, and analyze the needs of themselves and others. The same learning opportunities will benefit children with special needs and regular children. In children with special needs the benefits obtained in the form of the emergence of self-confidence, have the opportunity for adjustment, and readiness in facing social life. There are also benefits for the community to be able to learn about the limitations, strengths, and certain uniqueness of others so that they can develop social skills, foster a sense of empathy and sympathy (Kustawan, 2013). The supplementation of inclusive education is also expected to have implications for the perspective of parents of regular children so as not to discriminate against parents and children with special needs, and to be involved in supporting the inclusive education system.

\section{Conclusion}

The results of the questionnaire that have been distributed show that not all parents of children with special needs express strongly agree and agree to statements about inclusive education. Moreover, there are even parents of children with special needs who expressed doubts about statements about inclusive education. This shows that the 
views of parents are quite varied ranging from guidance, agree and strongly agree in preparing children with needs towards inclusive education. On the other hand, parents of children with special needs have high hopes for the implementation of inclusive education so that the rights of education in children with special needs can be achieved and children can develop optimally based on their potential and needs

\section{References}

Ainscow, M. (1999).Understanding the Development of Inclusive Schools. London: Falmer.

Ainscow, M. (2007).'From Special Education to Effective Schools for all: A Review of Progress so Far',in L. Florian (ed.)The SAGE Handbook of Special Education, pp.146-59.London:SAGE.

Amin, Baraktulllah. (2018). Peran Orang Tua Dalam Pendidikan Inklusif (Peran Orang Tua Anak Berkebutuhan Khusus Dalam Konteks Sekolah Inklusi). Prosiding Seminar Nasional Mendidik Anak Sehat dan Bahagia. Yogyakarta: Universitas Aisyyah Yogyakarta.

Amka. (2019). Pendidikan Inklusif Bagi Siswa Berkebutuhan Khusus di Kalimantan Selatan.Jurnal Pendidikan dan Kebudayaan Vol. 4, No. 1, DOI : 10.24832/jpnk.v4i1.1234

BoothT and Ainscow, M (eds). (1998). From Them to Us: An International Study of Inclusionin Education. London: Routledge

Darmono, Al. (2015). Peran Orang Tua Dalam Pendidikan Anak Berkebutuhan Khusus. Al Mabsut, Jurnal Studi Islam Dan Sosial Vol. 9, No. 1

Fraenkel Jr, Wallen N, Hyun H. (2012). How to Design and Evaluate Research in Education. New York: McgrawHill.

Frederickson, N., Dunsmuir, S., Lang, J., \& Monsen, J. J. (2004). Mainstream special school inclusion partnerships: pupil, parent and teacher perspectives. International Journal of Inclusive Education, 8(1), 37-57

Ilahi, Mohammad Takdir. (2013), Pendidikan Inklusif: Konsep dan Aplikasi. Jogjakarta: Ar-Ruzz Media.

Irkhamiyati. (2017). Evaluasi Persiapan Perpustakaan Stikes 'Aisyiyah Yogyakarta dalam Membangun Perpustakaan Digital. Berkala Ilmu Perpustakaan dan Informasi, Vol. 13, No. 1, Juni 2017, Hal. $37-46$ Doi: Http://10.22146/Bip.26086

Jauhari, Auhad. (2017). Pendidikan Inklusi Sebagai Alternatif Solusi Mengatasi Permasalahan Sosial Anak Penyandang Disabilitas. Jurnal Ijtimaiya _ Vol. 1 No. 1

Kantavong, P. (2018). Understanding inclusive education practices in schools under local government jurisdiction: a study of Khon Kaen Municipality in Thailand. International Journal of Inclusive Education,22:7, 767786, DOI: 10.1080/13603116.2017.1412509

Koster,K., Pijl, S.J., Nakken, H \& Houten, E.F. (2010). Social Participation of Students with Special Needs in Regular Primary Education in the Netherlands. International Journal of Disability, Development and Education Vol. 57, No. 1, 59-75.

Kustawan, D. (2013) Manajemen Pendidikan Inklusi. Jakarta: Luxima

Mustolih. (2018). Pendidikan Kesetaraan di Rumah Inklusif Desa Kembaran Kecamatan Dan Kabupaten Kebumen. Jurnal Pembangunan Pendidikan: Fondasi Dan Aplikasi Volume 6, No 1

Nakken, H., \& Pijl, S. J. (2002). Getting Along with Classmates in Regular Schools: A Review of the Effects of Integration on the Development of Social Relationships. International Journal of Inclusive Education, 6,4761.

Purwanta, Edi. (2002). Pendidikan Inklusif. UNY: PLB FIP.

Saputra, Angga. (2016). Kebijakan Pemerintah Terhadap Pendidikan Inklusif. Golden Age Jurnal Ilmiah Tumbuh Kembang Anak Usia Dini, Vol. 1 No. 3

Sunaryo. (2009). Manajemen Pendidikan Inklusif. Manjpendinklusi.Wordpres.

Surayya, Rahmi. (2018). Pendekatan Kualitatif dalam Penelitian Kesehatan. Jurnal Kedokteran dan Kesehatan Malikussaleh.

Tarnoto, N. (2016). Permasalahan-Permasalahan yang dihadapi Sekolah Penyelenggara Pendidikan Inklusi pada Tingkat SD. Jurnal Humanitas, Volume 13, Edisi 1, 50-6

Wijiastuti, Septi. (2018). Sikap Penerimaan Sosial Siswa Reguler Terhadap Siswa ABKdi Kelas Atas Sekolah Dasar Inklusi 1 Ngulakan Kulon Progo Yogyakarta. Yogyakarta: UNY. 